\title{
Forskning på bredden av vetenskapsområdet
}

\author{
Christina Nygren-Landgärds
}

De flesta skolämnen har på universitetsnivån en moderdisciplin som värnar om forskningen $i$ ämnets substansfrågor. Slöjd är ett skolämne som saknar en motsvarande moderdisciplin. Till exempel i Finland är slöjd ett eget vetenskapsområde, men placerat inom de pedagogiska vetenskaperna. Slöjd är dock ett mångfasetterat fenomen som behöver studeras i hela sin bredd för att utvecklas, inte enbart som ett skolämne. Syftet med denna artikel är att diskutera behovet av och utmaningar med forskning på bredden, d.v.s. forskning som tar fasta på både slöjdens kärna, den skapande processen och andra slöjdperspektiv. I artikeln diskuteras problematiken på ett teoretiskt allmänt plan. Den teoretiska diskussionen konkretiseras med tre utexaminerade masters reflektioner kring planeringen och genomförandet av en masteruppsats ${ }^{1}$ på bredden av vetenskapsområdet, d.v.s. forskning som inkluderar både en egen skapande process ${ }^{2}$ och pedagogisk/didaktiska perspektiv.

\section{Behov av breddad forskning}

Trots att slöjd ${ }^{3}$ har funnits som skolämne i de nordiska länderna allt sedan folkskolans införande i mitten av 1800-talet, så är forskningen inom dessa ämnen som en egen disciplin ung. Forskningen har fram till för några årtionden tillbaka skett inom ramen för närliggande vetenskapsområden. Forskare inom slöjdområdet har ändå samarbetat under lång tid och tillsammans byggt upp ett forskningsfält och en förståelse för vetenskapligt arbete inom slöjdområdet. Samarbetet har underlättats av en gemensam pedagogisk historia och forskningen har förtjänstfullt utvecklat den pedagogiska kunskapen om slöjd som skolämne, slöjdlärarens undervisning och slöjdelevens lärande. Marléne Johansson

\footnotetext{
${ }^{1}$ Masteruppsats avser i denna artikel ett examensarbete för högre högskolexamen, d.v.s. masterutbildning 300 ECTS. Examensarbetet benämns olika i de nordiska länderna och omfattar allt från 30 till 60 studiepoäng.

${ }^{2}$ Skapande process avser i denna artikel både design, planering och tillverkning av artefakter.

${ }^{3}$ Slöjd finns som skolämne i alla nordiska länder, men benämns olika och har olika innehåll. Det som de nordiska länderna har gemensamt är att slöjd och dess motsvarigheter är ett allmänbildande skolämne som grundar sig på en pedagogik som inkluderar elevers design, planering och tillverkning av artefakter i olika material.
} 
(2018) har analyserat tematiken i 100 nordiska doktorsavhandlingar med slöjdinnehåll och enligt henne är hela 49 avhandlingar inom det pedagogisk/didaktiska området. De övriga placerar hon inom historia, kulturvetenskap eller naturvetenskap. Juha Hartvik och Mia Porko-Hudd (2018) har analyserat forskning som är publicerad inom vetenskapsområdets tidskrift Techne serien. Även fokuseringen i artiklarna visar att de pedagogiska perspektiven har en stark ställning i slöjdforskningen. Hartvik och Porko-Hudd (2018) antar att en av orsakerna till detta kan vara att slöjden som vetenskapsområde är definierad som en pedagogisk vetenskapsdisciplin i Finland och att Finland har varit starkt framme i slöjdforskningen. Samtidigt finns det slöjdpedagogiska områden som inte alls diskuteras. Hartvik och Porko-Hudd (2018) konstaterar att bland annat slöjdverksamhetens betydelse i arbetslivet, slöjd i medierna, slöjd bland äldre människor och i tidiga barnaår, slöjd som fritidssysselsättning och slöjd i olika länder är svagt representerat i slöjdforskningen.

Det är av stor vikt att även ämnessubstansen studeras för att kunskapen inom vetenskapsområdet ska utvecklas och att studerande har möjlighet att fördjupa sina egna slöjdkunskaper och -färdigheter. Enligt Seija Kojonkoski-Rännäli (1995) kräver slöjdkunnande mångsidig skicklighet. Slöjdkunnande inkluderar kognitiva färdigheter såsom tänkande och problemlösningskunskaper, fysiska färdigheter såsom hand-öga-koordinationsförmåga, rumslig uppfattning, skicklighet, noggrannhet och hastighet samt social färdighet och kulturell känslighet. Juhani Peltonen (2001) definierar slöjd som ett mångfasetterat filosofiskt fenomen. Enligt honom är slöjd en mänsklig verksamhet där slöjdaren gestaltar sin egen livssyn genom produktidéer. Gestaltningen av produktidén ändrar vartefter att slöjdprocessen går vidare och produkten tar form. Då tar frågor om produkten som en bestående artefakt och teknologiska lösningar vid. I förverkligandet av produktidén resonerar slöjdaren även kring slöjdverksamhetens följdverkningar. Detta slöjdkunnande har genom tiderna överförts från generation till generation.

I dagens samhälle kan man inte länge utgå från att alla har möjlighet att tillägna sig slöjdkunnande i hemmet eller vid sidan av det lärande som sker inom skolslöjden. Kajsa Borg (2007) konstaterar i en artikel där hon analyserar vad akademiseringen av lärarutbildningen i slöjd har inneburit, att reformen betytt mindre tid för studier i slöjdämnet och att forskningstraditionen i slöjd är svag. Om slöjdkunnandet är svagt på praktisk nivå och det inte heller ges omsorg för inom forskningen, finns det risk för att kunskaperna om slöjdkunnande försvagas i samhället. För att garantera att hela slöjdområdet fortsättningsvis utvecklas behöver forskningen och universitetsundervisningen ta tag i både slöjdsubstansen och de pedagogisk/didaktiska frågorna. Detta framhålls av bland andra Laila Fauske (2016) som betonar att förutom organiserad utbildning inom 
slöjdområdet på alla nivåer i utbildningssystemet så är det viktigt att ämnesområdet och dess intressenter är en del av forskningssamfundet. En viktig aspekt är enligt henne en djupare diskussion om både ämnets teori och praktik eller både yrke och akademi.

\section{Slöjdperspektiv}

Forskning på bredden av slöjd kan beskrivas i linje med Pirkko Anttilas definition av slöjdvetenskap som vetenskapsområde och slöjdens olika perspektiv:

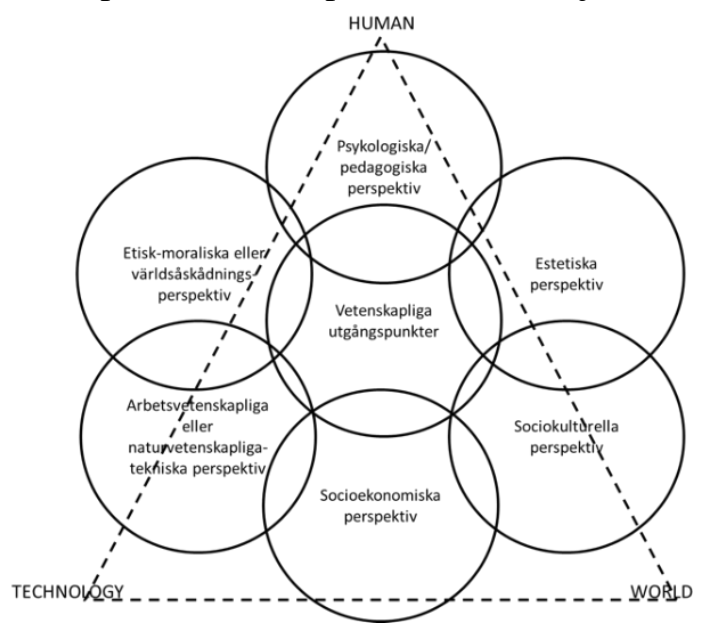

Figur 1. Slöjdens olika perspektiv (bearbetad modell utifrån Anttila, 2013, s. 129)

Anttilas (2013) modell visar att slöjdvetenskapen är ett vetenskapsområde som inkluderar tre huvudingredienser: människan, teknologin och omvärlden. Modellen visar även centrala vetenskapliga utgångspunkter i de områden som bildas mellan människa, teknologi och omvärld: det psykologisk/pedagogiska perspektivet, det estetiska perspektivet, det sociokulturella perspektivet, det socioekonomiska perspektivet, det arbetsvetenskapliga eller naturvetenskapliga-tekniska perspektivet och det etisk-moraliska eller världsåskådningsperspektivet. Med hänvisning till Johanssons (2018) och Hartvik och PorkoHudds (2018) analys av forskningen inom slöjdområdet kan man säga att forskningen i hög grad fokuserat på det psykologisk/pedagogiska perspektivet som syns i toppen av modellen, medan det finns mindre forskning inom de fem övriga områdena. Forskning på bredden av slöjd inkluderar således flera av de forskningsfält som definierats inom slöjdforskningen. Ulla Suojanen (1993) beskriver slöjdverksamhetens utgångspunkter enligt modellen i figur 2 . 


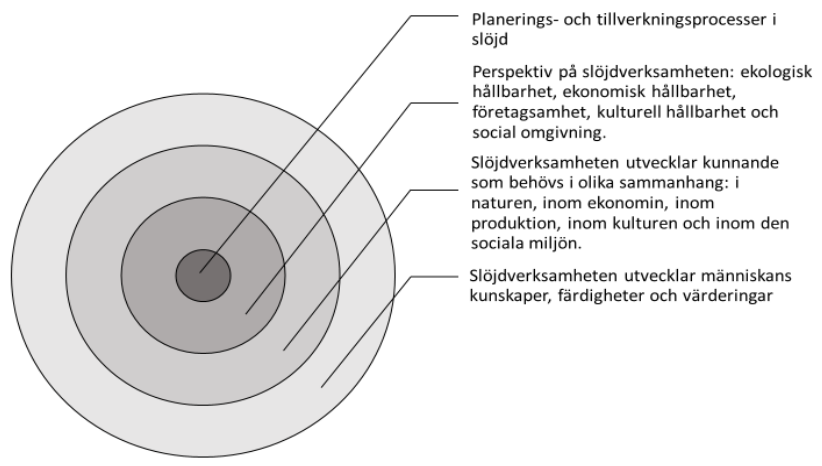

Figur 2. Slöjdverksamhetens utgångspunkter (bearbetad och översatt modell utifrån Suojanen, 1993, s. 24).

Suojanens (1993) modell visar hur delområden i slöjdverksamheten relaterar till varandra. I kärnan finns planerings- och tillverkningsprocesser i slöjd. Då man analyserar slöjdprocesserna kan man ha fokus på ett perspektiv, till exempel ekologisk hållbarhet, men i slöjdprocesserna samverkar detta perspektiv med övriga perspektiv. Modellen visar att slöjdverksamheten utvecklar kunnande inom flera områden och ytterligare, att detta kunnande består av både kunskaper, färdigheter och attityder. Det är för omfattande att samtidigt forska kring alla de företeelser som finns relaterade till slöjdprocessen. Forskaren behöver därför begränsa sig till ett fokusområde. Begränsningen hjälper forskaren att formulera forskningsfrågan.

Lindfors (2000) och Nygren-Landgärds (1997, 2000) har utvecklat modeller av slöjdpedagogik som verklighets- och vetenskapsfält. Modellen i figur 3 visar slöjd som pedagogisk vetenskapsdisciplin. I detta forskningsperspektiv utgår man från pedagogisk/didaktiska perspektiv och ställer dessa i relation till slöjdverksamhet. Forskningen är nära anknuten till andra pedagogiska vetenskapsområden, men även till humaniora, kulturvetenskaper, naturvetenskaper och samhällsvetenskaper. Modellen i figur 3 visar också att slöjd är ett skolämne på olika nivåer i utbildningssystemet. Forskningen kan bli för arbetsdryg om man inte begränsar sig till en utbildningsnivå eller årskurs. För att göra forskningen hanterbar behövs även val av didaktiskt fokus, till exempel ett undervisningsinnehåll, lärarens undervisning eller elevens lärande. 


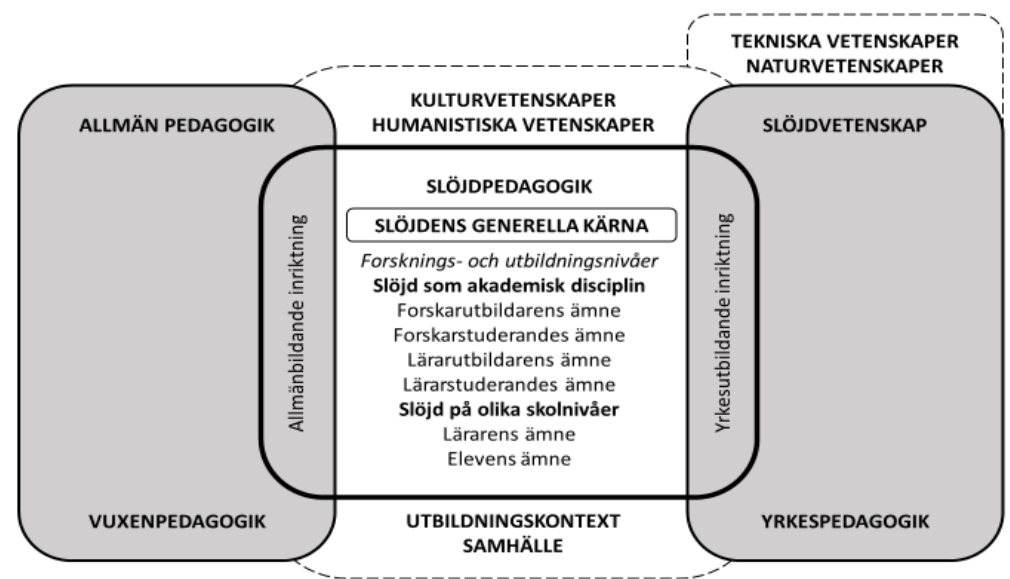

Figur 3: Den slöjdpedagogiska forskningens verklighets- och vetenskapsfält samt relationerna till gränsvetenskaperna (bearbetad modell utifrån Lindfors, 2000, s. 30).

Genom att ta fram mer forskning om slöjdämnets olika perspektiv (se figur 1 och 2) och slöjddidaktik/slöjdpedagogik (figur 3) kan vi utveckla en bättre helhetsförståelse av slöjd som fenomen och verksamhetsområde i både skola, samhälle och näringsliv, men även som mänsklig verksamhet. Undervisningen vid universiteten ska vara forskningsbaserad. I universitetsundervisningen i slöjd och i slöjdlärarutbildningarna kan vi med breddad slöjdforskning stödja de studerandes intresse som inte vill bli lärare utan enbart intresserar sig för ämnet slöjd och vi kan stödja den dubbla identiteten som slöjdare och lärare hos de som vet att de vill bli lärare.

\section{Slöjd i lärarutbildningen}

Att kunna känna sig professionell inom det område man studerar torde vara varje studerandes mål med sina studier. Detta gäller även lärarstuderande. Borg (2007) konstaterar:

Lärare som känner sig kompetenta och trygga, har bättre förutsättningar att kunna inspirera och stimulera eleverna till att frångå det kända och traditionella, så att eleverna utvecklar ett experimentellt och prövande förhållningssätt till sina slöjdprojekt. (Borg, 2007, s. 222-223.)

Motsvarande resonemang förs inom andra läroämnen. Till exempel Anna Toropova (2020) har i sin avhandling undersökt hur lärares kunskaper i matematik påverkar elevernas lärande. Hon konstaterar att det finns en samstämmighet mellan "lärarkvalitet" och elevernas lärande. Med lärarkvalitet avser hon lärarens ämneskunskaper och lärarerfarenhet. 
Även Hannah Kaihovirta (2018) har beforskat motsvarande tematik med basen i konstundervisningen i klasslärarutbildning. Hon konstaterar att "en av de stora utmaningarna i att arbeta med konstbaserade lärprocesser med lärarstuderande är att på ett kvalitativt sätt föra fram möjligheten att förstå hur konstbaserade lärprocesser kan tillföra mening i undervisning”. (Kaihovirta, 2018, s. 89.) Kaihovirta (2018) strävar efter att i undervisningen visa på hur erfarenheter och kunskap om konstnärliga lärprocesser kan skapa nya former av undervisning. Det är således ett sätt att sammanbinda studerandes lärande i konstprocessen samtidigt som de uppövar sin didaktiska förståelse. Kaihovirta (2018) konstaterar att i de konstbaserade lärprocesserna känns lärandet $i$ hela kroppen.

Forskning visar sålunda att universitetsstuderande behöver fördjupa både sina ämneskunskaper och sin undervisningsförmåga för att få god "lärarkvalitet" och att studier i ämnet och didaktiken kan gå hand i hand. Kaihovirtas (2018) studie visar också hur den studerande utvecklar sin didaktiska förståelse i samband med genomförandet av en konstprocess. Kaihovirtas (2018) resonemang kan förstås som att både den skapande processen och det didaktiska perspektivet behöver studeras, analyseras, diskuteras och sättas ord på för att den studerande ska utveckla sina kunskaper i ämnet som helhet.

\section{Reflektioner på breddad forskning}

För att utveckla både den didaktiska och den ämnesmässiga kunskapen inom kunst og håndverksfaget ${ }^{4}$ har man vid Universitetet i Sørøst-Norge (USN) valt att bygga upp masterstudierna så att de möjliggör både fördjupning $\mathrm{i}$ ämneskunskaperna och studier för läraryrket. I marknadsföringen av utbildningen konstaterar USN:

Dette er mastergraden for deg som vil gå i dybden på design, kunst og håndverk. Dette er også studieprogrammet for deg som vil være med å gjøre design, kunst og håndverk til et bedre fag. Her blir nemlig fagfeltet ditt eget forskningsområde, så kanskje vil du være den som oppdager helt nye sider ved kunst og håndverk som ingen før deg har dokumentert. Studiet lar deg fordype deg i lærebøker og læremidler i kunst og håndverk, der du kan finne muligheter til forbedring. Du kan studere pedagogiske spørsmål samtidig som du arbeider praktisk med bilde, skulptur eller installasjon. (USN, 2020)

\footnotetext{
4 "Kunst og håndverk" är ett skolämne i Norge. Det är ett brett skolämne som omfattar t.ex. både skolämnena slöjd och bild så som de beskrivs i Sverige. För mer information om skolämnet, se t.ex. Steinar Kjosavik (2001) som belyser skolämnets utveckling från 1889 till dagens skolämne och Liv Merete Nielsen och Ingvild Digranes (2012) som diskuterar utbildningssystemets utmaningar för att främja designkompetens på olika utbildningsnivåer.
} 
Masterstudierna avslutas med en "masteroppgave"5. I denna krävs på motsvarande sätt att de studerande ska inkludera både en didaktisk del och en skapande del. Den didaktiska delen kan vara en s.k. teoretisk studie eller en empirisk studie, medan den skapande delen ska inkludera den studerandes egen skapande process. Båda delarna ska vara vetenskapligt uppbyggda, genomförda och redovisade, men den studerande kan välja att fokusera mer på den ena delen än den andra, beroende på intresse och önskemål om fördjupning. Masteruppsaten ska resultera dels i en skriven rapport, dels i en utställning som belyser den skapande processen och gärna forskningen som helhet. Många studerande väljer att genomföra två utredningar i relation till sina forskningsfrågor: dels en undersökning av, inom eller om den egna skapande processen, dels en undersökning med fokus på didaktiska frågor.

Ella Melbye (2013) har analyserat examensarbeten vid USN och vad studenter valt att fokusera sin forskning på. Enligt Melbye (2013) är studerande särskilt intresserade av att forska kring den skapande verksamheten i form av "å forme". Hon konstaterar att formandet har en bred betydelse i uppsatserna och att det handlar både om interaktionen mellan konst- och kulturuttryck, processer, produkter och reflektion. Syftet är i många fall att skapa eller bygga förståelse för relationer mellan individ och kultur. Det kan handla om både personlig och objektiv kunskap. Individen som fokuseras i forskningen kan vara studenten själv eller en annan person. Då det sociala rummet fokuseras kan det handla om rummet "här och nu" eller ett större, t.o.m. globalt rum. I masteruppsatserna avser man med kultur dels den kultur man har, dels den kultur som finns. Kraven på utformningen av masteruppsatsen kan förstås i den kontext och i relation till den historia som det norska skolämnet "kunst og håndverk" har utvecklats. Laila Fauske (2016) beskriver relationen mellan utvecklingen av skolämnet "kunst og håndverk" och forskningens bredd. Hon identifierar en tydlig koppling mellan ett ökat fokus i skolan på design, arkitektur, konst och visuell kommunikation och bredden av de yrken området kan relateras till. Processen är enligt henne en kunskapsprocess där kunskapsbasen skolämnet har flyttats från ett yttre till ett inre perspektiv. Utvecklingen av forskningen har enligt henne varit avgörande för att kunna se handlingsaspekten och teorin som en helhet och för att bygga och utveckla ämnesområdet inifrån.

Vid USN har man således valt att kräva både ett ämnesmässigt, skapande innehåll och ett pedagogisk/didaktiskt innehåll i studenternas masteruppsatser. USN:s val att fokusera på bredden av vetenskapsområdet är intressant i denna artikel som lyfter fram behovet av en bredare forskning inom vetenskapsområdet. Allmänt sett kan man tänka sig att dylika forskningsuppdrag är för

\footnotetext{
5 "Masteroppgave i design, kunst og håndverk" vid USN omfattar 60 ects.
} 
omfattande, för spretigt och metodologiskt omöjligt. Genom att ta del av studerandes upplevelser av masteruppsatser som är på bredden av vetenskapsområdet är det möjligt att belysa utmaningar, förtjänster och problematik i sådan forskning.

Således ombads tre nyutexaminerade från USN:s masterutbildning i "design, kunst og håndverk" att reflektera på sin process kring masteruppsatsen. Reflektionen skulle vara fritt formulerad och som stöd i tanken uppgavs stickord som "lätt", "svårt", "utmanande", "roligt", o.s.v. De ombads också reflektera kring uppdraget att uppsatsen skulle bestå av både en egen skapande process och ett didaktiskt perspektiv.

Tabell 1. Presentation av informanter (fingerade namn).

\begin{tabular}{|l|l|}
\hline Sonja & $\begin{array}{l}\text { Hon valde att forska kring ett undervisningsupplägg och fördjupa sin } \\
\text { förståelse för undervisningsinnehållet genom en egen skapande process. I } \\
\text { masteruppsatsen sammanflätas resultaten kring undersökningen om } \\
\text { undervisningsupplägget med den kunskap och de erfarenheter hon } \\
\text { dokumenterat i sin skapande process. }\end{array}$ \\
\hline Lisa & $\begin{array}{l}\text { Hon har tagit fram ett kreativt dokumenterings- och arbetssätt som hon i } \\
\text { masteruppsatsen testar i skolsammanhang. I masteruppsatsen binder hon } \\
\text { samman sina egna erfarenheter av arbetssättet med elevers dokumentation av } \\
\text { sina erfarenheter till en bred förståelse av hur arbetssättet fungerar i } \\
\text { skolsammanhang. }\end{array}$ \\
\hline Kalle & $\begin{array}{l}\text { Han ville inledningsvis fokusera på sin skapande process, men valde att } \\
\text { intervjua lärare om ett undervisningsinnehåll inom hans intresseområde. } \\
\text { Resultaten från den didaktiska undersökningen använde han som } \\
\text { observationsgrund i sin egen skapande process. I masteruppsatsen diskuterar } \\
\text { han undervisningsinnehållet utifrån didaktisk teori och utifrån erfarenhet } \\
\text { baserat på både intervjuer och den egna skapande processen. }\end{array}$ \\
\hline
\end{tabular}

I sammanställningen nedan har informanternas reflektioner om processen kring masteruppsatsen återgetts som exemplifierande helheter för att återspegla variationen i resonemangen. Reflektionerna har kategoriserats enligt innehåll i "Val av fokus", "Genomförande", "Brett forskningsuppdrag" och "Reflektion om lärande". Innehåll i informanternas utsago som kan vara avanonymiserande har strukits och visas med X. 


\section{Tabell 2. Sammanställning av exempel på reflektioner om processen kring masteruppsatsen.}

\begin{tabular}{|c|c|c|c|}
\hline \multicolumn{4}{|c|}{ Master } \\
\hline & Sonja & Lisa & Kalle \\
\hline 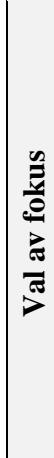 & $\begin{array}{l}\text { Eg valde tema X ut frå } \\
\text { eigen interesse. Så tok } \\
\text { eg den nye læreplana, } \\
\text { som trede i kraft } \\
\text { hausten } 2020 \text {, og såg } \\
\text { spesielt på Overordna } \\
\text { del ... Så eg bestemte } \\
\text { meg ut frå kva som } \\
\text { interesserte meg for og } \\
\text { kva som var nyttig i } \\
\text { samanheng med yrket } \\
\text { mitt. Kva eg hadde } \\
\text { utbytte av i kvardagen. }\end{array}$ & $\begin{array}{l}\text { Jeg bestemte meg } \\
\text { for hva jeg skulle } \\
\text { undersøke basert på } \\
\text { hva jeg hadde lyst å } \\
\text { jobbe med og mine } \\
\text { egne interesser. Det } \\
\text { var veldig viktig for } \\
\text { meg å gjøre noe jeg } \\
\text { hadde lyst til for å } \\
\text { holde motivasjon og } \\
\text { interessen oppe i så } \\
\text { mange måneder. }\end{array}$ & $\begin{array}{l}\text { Min inngang til studiet og avhandlingen6 var } \\
\text { knyttet til et ønske om egenutvikling og større } \\
\text { innsikter innenfor X som et praktisk felt. } \\
\text { Utfordringen lå derfor i stor grad på å få mine } \\
\text { skapende prosesser til å ha relevans for andre, og } \\
\text { hvordan inkludere det didaktiske på en god måte, } \\
\text { der det var en naturlig del av oppgaven X. }\end{array}$ \\
\hline & $\begin{array}{l}\text { Eg ville unders } \varnothing \text { kje } \\
\text { elevane sin prosess og } \\
\text { det vart difor naturleg } \\
\text { å gjennomføre } \\
\text { undersøkinga i ein } \\
\text { undervisningssituasjon } \\
\text {. For at eg kunne være } \\
\text { både deltakande lærar } \\
\text { og forskar var eg } \\
\text { avhengig av å kunne ta } \\
\text { videoopptak. Dette } \\
\text { gjorde undersøkinga } \\
\text { meir interessant, trur } \\
\text { eg, fordi eg da kunne } \\
\text { konsentrere meg om } \\
\text { elevane først og så } \\
\text { observere i etterkant } \\
\text { gjennom opptaka. }\end{array}$ & $\begin{array}{l}\text { Det som var lett, var } \\
\text { å skrive om egen } \\
\text { prosess. Det var noe } \\
\text { jeg synes var gøy og } \\
\text { som jeg fikk bra til. } \\
\text { Det var også lettere } \\
\text { enn jeg trodde å } \\
\text { tolke og analysere } \\
\text { intervjuene jeg } \\
\text { gjennomførte. Jeg } \\
\text { tror jeg synes dette } \\
\text { var lettere fordi det } \\
\text { ikke var like mange } \\
\text { av de faste reglene } \\
\text { som i andre kapitler. } \\
\text { Det var basert på } \\
\text { min egen erfaring og } \\
\text { ikke på en oppskrift. }\end{array}$ & $\begin{array}{l}\text { I min oppgave startet jeg med unders } \emptyset \text { kelser i } \\
\text { skolen. Gjennom en større unders } \emptyset \text { kelse blant } \\
\text { lærere på KDA, så en hvordan dette ble en } \\
\text { hovedvekt for oppgaven. En stor utfordring ble } \\
\text { videre hvordan et skapende arbeid kunne ha } \\
\text { sammenheng med denne undersøkelsen. Fokuset i } \\
\text { forskningen ble knyttet opp X didaktikk etter } \\
\text { gjennomført intervjuundersøkelse i den } \\
\text { videregående skolen. Slik jeg så det, var det } \\
\text { nødvendig å fokusere på det didaktiske, for at dette } \\
\text { skulle bli en helhetlig del av oppgaven, og ikke bare } \\
\text { et vedheng. } \\
\text { Et stort spørsmål som dukket opp underveis i denne } \\
\text { prosessen, er også i hvor stor grad egne skapende } \\
\text { prosesser faktisk har relevans for andre isolert sett? }\end{array}$ \\
\hline
\end{tabular}

\footnotetext{
${ }^{6}$ Informanterna använder begreppet avhandling för det som i denna artikel benämns masteruppsats.
} 
Slöjdkunnande i förändring - Slöjdkunnande: utmaningar och återupptäckter

\begin{tabular}{|c|c|c|c|}
\hline 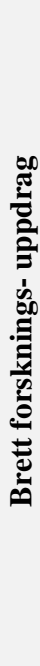 & $\begin{array}{l}\text { Eg opplevde denne } \\
\text { blandinga som svært } \\
\text { givande da eg pga. } \\
\text { denne inndelinga } \\
\text { kjende at masteren } \\
\text { ville gi meg nytting } \\
\text { kunnskap for yrket } \\
\text { mitt. Eg valde å ha ein } \\
\text { stor didaktisk del fordi } \\
\text { det gav meg størst } \\
\text { meining. }\end{array}$ & $\begin{array}{l}\text { Jeg likte å blande } \\
\text { min egen kreative } \\
\text { prosess og en } \\
\text { didaktisk del. Det } \\
\text { var fint å kunne } \\
\text { inkludere både } \\
\text { kreativt og didaktisk } \\
\text { arbeid, siden det er } \\
\text { nettopp dette jeg } \\
\text { interesserer meg for } \\
\text { og som jeg vil jobbe } \\
\text { med og lære mer } \\
\text { om. Jeg var glad for } \\
\text { at oppgaven var slik. }\end{array}$ & $\begin{array}{l}\text { I avhandlingen er det krav om begge elementene, } \\
\text { noe som gjør at oppgaven i seg selv er vidt. } \\
\text { Samtidig er en erfaring gjennom studiet at disse to } \\
\text { elementene i en del tilfeller fremstår som } \\
\text { motsetninger. Gjennom didaktikken har vi fått } \\
\text { fokus på det forskningsbaserte, der en ønsker å } \\
\text { systematisere, konkretisere og bryte ned elementer } \\
\text { til det forståelige. Noe som igjen er svært viktig for } \\
\text { å forstå læringsprosesser og forbedre disse. } \\
\text { Innenfor det kunstfaglige har en i del } \\
\text { sammenhenger blitt dyttet mer mot en modernistisk } \\
\text { kunstforståelse/praksis, der kunsten og det praktiske } \\
\text { dras mot en mer filosofisk, subjekt og abstrakt } \\
\text { retning. Inkludering av begge disse elementene i en } \\
\text { og samme oppgave fremstår svært krevende. } \\
\text { Samtidig er en erfaring at disse delvise } \\
\text { motsetningene har gjort at må utfordre seg selv på å } \\
\text { finne sammenhenger og fordype seg grundig i } \\
\text { feltet. }\end{array}$ \\
\hline 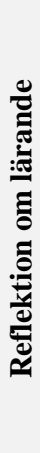 & $\begin{array}{l}\text { Det kjennes godt å ha } \\
\text { fullført og gjort det bra } \\
\text { på masteren. } \\
\text { Mestringskjensle på } \\
\text { høgt plan. Det kjennes } \\
\text { og godt ut å ha bidratt } \\
\text { med forsking som } \\
\text { nokon kan ha bruk for. } \\
\text { Eg meiner det er bruk } \\
\text { for den iallfall fordi } \\
\text { den er så knytt opp } \\
\text { mot læreplana og } \\
\text { undervisning i faget. }\end{array}$ & $\begin{array}{l}\text { Det jeg merker mest } \\
\text { i ettertid er at jeg } \\
\text { ikke bryr meg om } \\
\text { karakter, vurderinger } \\
\text { og slike ting. Det } \\
\text { som betyr noe for } \\
\text { meg er min egen } \\
\text { erfaring. Jeg vet } \\
\text { hvor hardt jeg jobbet } \\
\text { og hvor mye jeg } \\
\text { lærte, og det er det } \\
\text { eneste jeg bryr meg } \\
\text { om. }\end{array}$ & $\begin{array}{l}\text { Prosessen har gitt dybdeinnsikter innenfor X feltet } \\
\text { som jeg på langt nær hadde tidligere. Prosessen } \\
\text { har også gitt nye innsikter innenfor didaktikken og } \\
\text { hvordan det arbeides innom X i den videregående } \\
\text { skolen. Noe som vil kunne være til stor hjelp for } \\
\text { egen undervisning i skolen. Gjennom prosessen har } \\
\text { en også blitt mer bevisst på egne læringsprosesser } \\
\text { og arbeidsmåter. Noe som er viktig for videre } \\
\text { læring og arbeidsliv. }\end{array}$ \\
\hline
\end{tabular}

\section{Val av forskningsobjekt och fokus i masteruppsatsen}

Då det inte finns mycket forskning på doktors- och postdoktors nivå, som kan fungera som förebild för hur man i forskning kan kombinera det egna skapande arbetet med en didaktisk undersökning, är mastersstudenterna vid USN i många fall pionjärer inom den forskningstematik som de valt att fördjupa sig i. Informanternas reflektioner visar att val av tematik, forskningsfråga och fokus i masteruppsatsen var utmanande. Kalle uppger att det var svårt att hitta gemensamma nämnare mellan den egna skapande processen och de didaktiska spörsmålen. Detta kan bero på att problematik som man vill undersöka i den skapande processen är ofta personnära och ibland svår att formulera med ord, medan de didaktiska frågorna kan vara av mer allmän natur och inte relatera till personlig erfarenhet. 
Begränsningen av den problematik man vill undersöka till en gripbar problemställning är svår då allt verkar påverka och höra ihop med allt. Men just därför är begränsningen nödvändig. Den gör forskningen hanterbar. För att göra arbetet med masteruppsatsen hanterbar som en helhet sökte informanterna efter en kontaktyta mellan de två perspektiven i uppsatsen. Sonja valde till slut ett perspektiv som hon kan ha nytta av i sin vardag som lärare, Lisa valde ett perspektiv som utgick från hennes skapande arbete för att hon skulle hålla sig motiverad genom hela processen och Kalle ville fördjupa sig i en egen skapande process, men valde att utgå från en didaktisk undersökning för forskningsmetodikens skull. Kalle uppger även att han tänkte att didaktisk forskning kan vara mer intressant även för andra än honom själv. Kalles resonemang visar att det kan vara problematiskt att tänka sig att forskning kring den egna skapande processen kan vara värdefull för vetenskapsområdet då forskningstraditionen utifrån detta perspektiv är svag.

\section{Genomförande}

Beroende på fokuseringen i masteruppsatsen och forskningsfråga väljs forskningsansats. Valet av forskningsansats och -metoder är viktigt för att man ska kunna få fram den information som behövs för just det fenomen man vill undersöka. Därför besluter man om forskningsansats och -metod utifrån problem, inte problem utifrån metod. Utifrån reflektionerna ovan kan man se att Lisa kände sig ensam i sitt arbete och skulle ha velat ha mer samarbete och gemenskap med andra. En orsak till detta kan vara att forskningsmetodiken inte är lika tydligt formulerad för forskning om den skapande processen och att pionjärsuppdraget blev för tungt att axla.

Forskning i den egna skapande processen och i den egna undervisningen är en utmaning eftersom forskaren har flera roller i processen. Forskaren är både konstnären, läraren och forskaren. I forskningsprocessens olika skeden gäller det att skilja på rollerna. Kalle berör denna problematik då han konstaterar att han valde att inleda forskningsprocessen i det didaktiska perspektivet emedan metoderna är mer tydliga för den typen av forskning. Han tänkte också att det kan vara svårt att med ett utifrånperspektiv analysera det egna skapande arbetet för att finna ny kunskap. Sonja å sin sida upplevde att det var en fördel för forskningen att hon valde en sådan datainsamlingsmetod som möjliggjorde både lärar- och forskarrollen på ett naturligt sätt.

\section{Reflektioner om det breda forskningsuppdraget och lärande}

Alla tre informanter anser att det breda forskningsuppdraget, det vill säga att ha både ett didaktiskt perspektiv och en egen skapande process i forskningsupplägget, är bra och att det varit en lärorik process. Sonja ser att dubbelheten har gett henne de kunskaper och insikter hon behöver som lärare och är glad över 
den nya kunskap hon kunnat bidra med inom det didaktiska fältet. Lisa lyfter fram att det dubbla sättet att arbeta var bra för henne eftersom det är så hon gillar att arbeta. Genom masteruppsatsen har hon blivit mer säker på sig själv och bryr sig nu mer om sina egna erfarenheter än om andras bedömning av hennes arbete. Kalle såg utmaningen med att sammanföra ett abstrakt resonemang om skapande arbete med ett mer konkret resonemang om didaktik som mycket spännande och konstaterar att han genom processen kring masteruppsatsen har lärt sig mer om sitt eget lärande och sina egna arbetssätt. Resonemangen visar på mångsidigheten i vetenskapsområdet. Man kunde karaktärisera perspektivet på Sonjas resonemang som lärarens perspektiv, Lisas resonemang som kunst og håndverk utövarens perspektiv och Kalles resonemang som forskarens perspektiv.

\section{Slutdiskussion}

Syftet med denna artikel var att lyfta upp diskussionen om behovet av och utmaningar med forskning på bredden, d.v.s. forskning som tar fasta på både slöjdens kärna, den skapande processen och andra slöjdperspektiv. Diskussionen i artikeln visar på behovet av slöjdforskning på bredden även på doktors och postdoktors nivå för att föra slöjden som vetenskapsområde framåt. Genom mer forskning på bredden av vetenskapsområdet blir det möjligt att definiera slöjden som egen vetenskaplig disciplin vid universiteten. Masterutbildningen i "design, kunst og håndverk" vid Universitetet i Sørøst-Norge föregår med goda exempel. I utbildningen kräver man att masteruppsaten skall ha ett brett innehåll. I artikeln exemplifieras därför problematiken och utmaningar i forskning som inkluderar både ett pedagogiskt/didaktiskt perspektiv och en egen skapande process med nyutexaminerade USN-masters reflektioner på sin forskningsprocess. De nyutexaminerades utsagor visar att utmaningarna finns vid val av tematik och metodologi som möjliggör forskning på bredden och i att sammanställa forskningen som en helhet då den innehåller både traditionell forskningslayout och praktiska moment och artefakter. Exemplifieringen ger därvid vid handen att forskningen inom slöjdområdet behöver fokusera på att utveckla forskningsmetodologi som förmår ta i beaktande det breda vetenskapsområdet. Definitioner av slöjd som väsen, som skolämne och som vetenskapsområde och analyser av slutarbeten och doktorsavhandlingar ger verktyg för hur det område man studerar kan beskrivas. Det hjälper forskaren att fokusera och begränsa sitt forskningsområde. Men beskrivningar av slöjd som fenomen och forskningsfält ger ändå inte konkreta verktyg för planering av forskning som fokuserar på slöjdens bredd och som även inkluderar en skapande process. Diskussionen i artikeln ger därmed antydningar om att det är en utvecklad forskningsmetodologi som är nyckeln för fortsatt utveckling av slöjd som vetenskapsområde. 


\section{Referenser}

Anttila, P. (2013). Slöjd som vetenskap. I J. Sandven (red.) Jubileum og visjoner - 75 år på Notodden. September 2013 (s. 120-129). Notodden: Høgskolen i Telemark.

Borg, K. (2007). Akademisering - en väg till ökad professionalism i läraryrket? Pedagogisk Forskning i Sverige, Vol. 12, nr. 3, 211-225.

Fauske, L. B. (2016). Reforhandling av kunnskapsgrunnlag. Forskning og fagutvikling med utspring i designdidaktikk. Techne serien - Forskning i slöjdpedagogik och slöjdvetenskap, 23(2), 50-68. Hämtad från https://journals.oslomet.no/index.php/techneA/article/view/1560

Hartvik, J., \& Porko-Hudd, M. (2018). Slöjdforskning i fokus: Techne serien 1995-2017. Techne serien - Forskning i slöjdpedagogik och slöjdvetenskap, 25(3), 94-108. Hämtad från https://journals.oslomet.no/index.php/techneA/article/view/3030

Johansson, M. (2018). Doktorsavhandlingar inom det nordiska slöjdfältet. Techne serien Forskning i slöjdpedagogik och slöjdvetenskap, 25(3), 109-123. Hämtad från https://journals.oslomet.no/index.php/techneA/article/view/3031

Kaihovirta, H. (2018). I CAN FLY. Juxtaposition lärarutbildare - klasslärarstuderande. Konstbaserade lärprocesser som bildkonstdidaktisk erfarenhet. Journal for Research in Arts and Sports Education, Special Issue: Å forske med kunsten. Vol.2, 86-107. https://doi.org/10.23865/jased.v2.962

Kjosavik, S. (2001). Fra tegning, slфyd og håndarbeid til kunst og håndverk. En faghistorie gjennom 150 år. Vollen: Tell.

Kojonkoski-Rännäli, S. (1995). Ajatus käsissämme. Käsityön käsitteen merkityssisällön analyysi. (Doktorsavhandling. Fritt översatt: Tanken i våra händer. Analys av innebörden i begreppet handarbete.) Turku: Turun yliopisto.

Lindfors, L. (2000). Nordisk slöjdforskning. Fakta och funderingar inför projektsamarbete. Ingår i U. Suojanen \& M. Porko-Hudd (red.) World-Wide-Sloyd. Ideologi för framtidens samhälle. Dokumentationer från NordFo-symposium. Vasa, 26-27.11.1999. Techne serien. Forskning i slöjdpedagogik och slöjdvetenskap. B:8/2000. Vasa: NordFo.

Melbye, E. (2013). Det å forme i spennet mellom individ og kultur. Hovedfagsoppgaver i forming - Noen overveielser. I J. Sandven (red.) Jubileum og visjoner - 75 år på Notodden. September 2013 (s. 131-157). Notodden: Høgskolen i Telemark.

Nielsen, L. M., \& Digranes, I. (2012). Designkompetanse i et gjennomgående utdanningsløp. Techne serien - Forskning i slöjdpedagogik och slöjdvetenskap, 19(1), 17-24.. Hämtad från https://journals.oslomet.no/index.php/techneA/article/view/394

Nygren-Landgärds, C. (1997). Slöjdfostran i kulturkampen. Del VI. Det tänkta och det upplevda undervisningsämnet. En studie om undervisning i slöjdpedagogik. Rapporter från Pedagogiska fakulteten vid Åbo Akademi nr 15/1997. Vasa: Åbo Akademi.

Nygren-Landgärds, C. (2000). Educational and Teaching Ideologies in Sloyd Teacher Education. Åbo: Åbo Akademi University Press.

Peltonen, J. (2001). Den slöjdpedagogiska teorins filosofiska grunder. Ingår i C. NygrenLandgärds \& J. Peltonen (red.) Visioner om slöjd och slöjdpedagogik. Techne serien. Forskning i slöjdpedagogik och slöjdvetenskap. B:10/2001. Vasa: NordFo.

Suojanen, U. (1993). Käsityökasvatuksen perusteet. [Slöjdpedagogikens grunder.] Borgå: WSOY

Toropova, A. (2020). Teachers meeting the challenges of the Swedish school system. Agents within boundaries. (Doktorsavhandling) Göteborg: Göteborgs universitet. 
Universitetet i Sørøst-Norge (USN) (2020). Master i design, kunst og håndverk.

https://www.usn.no/studier/finn-studier/kunst-handverk-og-musikk/master-i-designkunst-og-handverk/

Christina Nygren-Landgärds är professor i slöjdpedagogik vid Åbo Akademi, Finland. Sedan hösten 2020 är hon tjänstledig från denna professur och är professor i pedagogik vid universitetet i Agder, Norge. Som forskare inom slöjdpedagogik har hon särskilt intresserat sig för lärarutbildning och frågor som handlar om slöjdens pedagogiska uppdrag i samhällsutvecklingen. NygrenLandgärds har under lång tid haft ledningsuppdrag som dekan och vicerektor inom Åbo Akademi vilket har styrt hennes forskningsintresse till frågor om utveckling och ledning av universitetet som utbildningsorganisation. För närvarande leder hon ett projekt med fokus på hur nordiska universitet beskriver och handskas med fenomenet kvalitetskultur. 